Aquaculture

February 2015, Volume 437, Pages 132-317

http://dx.doi.org/10.1016/j.aquaculture.2014.12.003

http://archimer.ifremer.fr/doc/00240/35171/

(c) 2014 Elsevier B.V. All rights reserved.

\title{
Scallop larval survival from erythromycin treated broodstock after conditioning without sediment
}

\author{
Holbach Marine ${ }^{1,2}$, Robert Rene ${ }^{2,3}$, Boudry Pierre ${ }^{2}$, Petton Bruno ${ }^{2}$, Archambault Philippe ${ }^{1}$, \\ Tremblay Rejean ${ }^{1, *}$
}

\footnotetext{
${ }^{1}$ Institut des Sciences de la Mer, Université du Québec à Rimouski, 310 allée des Ursulines, G5L 3A1 Rimouski, Québec, Canada

2 Ifremer, Laboratoire des Sciences de I'Environnement Marin (UMR 6539 LEMAR), Centre Bretagne -

ZI de la Pointe du Diable - CS 10070 - 29280 Plouzané, France

${ }^{3}$ Ifremer, Unité Littoral, Centre Bretagne - Zl de la Pointe du Diable - CS 10070 - 29280 Plouzané, France

*Corresponding author : email address : rejean tremblay@uqar.ca
}

\begin{abstract}
:
Pathogenic bacteria are known to be one of the main factors affecting Pecten maximus larval survival in hatcheries. As a result, juvenile production often relies on the use of antibiotics during larval culture. However, limitations of the usage of chemicals such as chloramphenicol in aquaculture have been reinforced due to their negative environmental impact and alternatives are accordingly needed. Thus, the importance of bacterial transfer from oocytes to larvae has been studied here as well as procedures to limit larval mortality in P. maximus. In order to reduce bacterial contamination during larval development, we focused on two periods, broodstock conditioning and post-fertilization. The animals were conditioned for 2 months with two erythromycin treatments of 6 days, with (SA) or without sandybottom (NSA). The absence of sediment strongly reduced contamination by Vibrios of oocytes (NSA: $0.003 \pm 0.002$ CFU oocyte- 1SA: $0.57 \pm 0.17$ CFU oocyte- 1) and D-larvae (NSA: $0.14 \pm 0.05$ CFU oocyte- 1SA: $0.51 \pm 0.002$ CFU oocyte- 1 ). It also enhanced survival by $52 \%$ at 15 days post fertilization, whereas a two days antibiotic treatment of D-larvae did not improve subsequent survival, regardless of broodstock conditioning method. Furthermore, both treatments led to similar fatty acids profiles of oocytes and resulting larvae, suggesting that broodstock conditioning was physiologically similar with or without sediment. This work has shown that gametes contamination could be reduced when sandy-bottom was removed during broodstock conditioning under bacterial control with erythromycin. The present results contribute to a reduced utilization of antimicrobial agents for great scallop larval rearing in controlled condition.
\end{abstract}




\section{Highlights}

- The absence of sediment during scallop broodstock conditioning strongly reduced contamination by Vibrios of oocytes. It also enhanced larval survival by $52 \%$ at 15 days post fertilization. Two days antibiotic treatment of D-larvae did not improve subsequent survival, regardless broodstock conditioning method. The use of selected antibiotic targeted on broodstock for a brief and early antibiotic treatment depressed sharply bacterial flora.

Keywords : scallop, broodstock conditioning, larval survival, vibriosis 


\section{Abstract:}

Pathogenic bacteria are known to be one of the main factors affecting Pecten maximus larval survival in hatcheries. As a result, juvenile production often relies on the use of antibiotics during larval culture. However, limitations of the usage of chemicals such as chloramphenicol in aquaculture have been reinforced due to their negative environmental impact and alternatives are accordingly needed. Thus, the importance of bacterial transfer from oocytes to larvae has been studied here as well as procedures to limit larval mortality in P. maximus. In order to reduce bacterial contamination during larval development, we focused on two periods, broodstock conditioning and post-fertilization. The animals were conditioned for 2 months with two erythromycin treatments of 6 days, with (SA) or without sandy-bottom (NSA). The absence of sediment strongly reduced contamination by Vibrios of oocytes (NSA: $0.003 \pm 0.002 \mathrm{CFU}$ oocyte $^{-1} \quad$ SA: $\quad 0.57 \pm 0.17 \mathrm{CFU}^{\text {oocyte }}{ }^{-1}$ ) and D-larvae (NSA: $0.14 \pm 0.05 \mathrm{CFU}$ oocyte $^{-1} \mathrm{SA}: 0.51 \pm 0.002 \mathrm{CFU}$ oocyte $^{-1}$ ). It also enhanced survival by $52 \%$ at 15 days post fertilization, whereas a two days antibiotic treatment of D-larvae did not improve subsequent survival, regardless of broodstock conditioning method. Furthermore, both treatments led to similar fatty acids profiles of oocytes and resulting larvae, suggesting that broodstock conditioning was physiologically similar with or without sediment. This work has shown that gametes contamination could be reduced when sandy-bottom was removed during broodstock conditioning under bacterial control with erythromycin. The present results contribute to a reduced utilization of antimicrobial agents for great scallop larval rearing in controlled condition.

Key words: scallop, broodstock conditioning, larval survival, vibriosis. 


\section{Introduction}

Compared to oysters or clams (Loosanoff and Davis, 1963; Walne, 1966), the production of Pectinid juveniles for aquaculture, enhancement of populations or sea ranching through reliable hatchery processes is more recent (Dao et al., 1995; Helm et al., 2004). After the first laboratory trials (Gruffydd and Beaumont, 1972), seed supply by hatcheries progressed rapidly. First results of experimental production were encouraging (Buestel et al., 1982), but despite recent progress (Magnesen et al., 2006) juvenile production remains, however, unpredictable due to high variations in larval survival, often associated with massive bacterial infections (Andersen et al., 2011; Devauchelle and Mingant, 1991). To limit bacterial contamination and sustain production of juveniles, the preventive or systematic use of antimicrobial agents seems the solution for some Pectinid hatcheries (Le Pennec and Prieur, 1977; Nicolas et al., 1996; Robert et al., 1996; Torkildsen et al., 2005; Uriarte et al., 2001). Larval survival is generally improved but such a practice is unsustainable as it increases the risk of selecting resistant bacteria (Akinbowale et al., 2006; Riquelme et al., 1994, Cordero Otto et al., 2012).

Among heterotrophic bacteria, some Vibrios are known to be particularly virulent and have been reported to induce severe and rapid larval mortalities of molluscs (Elston and Leibovitz, 1980; Lambert et al., 1998; Lodeiros et al., 1987). Vertical transfer of bacteria from broodstock to gametes and larvae of different bivalve species has been described in many studies (AvendañoHerrera et al., 2001; Lodeiros et al., 1987; Prado et al., 2013; Riquelme et al., 1994) and could result in Pecten maximus in a transfer of bacteria from the intestinal loop to the gonad (Beninger et al., 2003; Le Pennec et al., 1992). For the contamination at early life stages, Vibrio were shown to be released into seawater rearing by Argopecten ventricosus during spawning, inducing bacterial blooms in tanks 24 h post-incubation (Sainz-Hernández and Maeda-Martínez, 2005). 
The main objective of the present study was to assess different possibilities to limit the microbial load in early life stages of $P$. maximus larvae. On one hand, the influence of sediment during broodstock conditioning was studied because we hypothesised that early gametes contamination might be induced during broodstock conditioning. Most bivalves do not need sediment to be conditioned in hatchery but scallops are generally maintained in tanks with sand or gravel to mimic their natural environment (Utting and Millican, 1997). This sediment could favour bacterial development by trapping microorganisms and becoming a potential gametes infection source. On the other hand, the hypothesis that a short and early treatment, target on broodstock bacterial flora, could noticeably reduce bacterial proliferation and accordingly enhance larval survival was studied. To determine the influence of the presence of sediment during broodstock conditioning on larval quality, fatty acids content and composition have been determined on each oocyte and D-larva sample. Total fatty acids accumulation and composition in bivalve larvae have been largely demonstrated to be a good indicator of larval quality (Delaunay et al., 1992; Gagné et al., 2010; Glencross and Smith, 2001; Le Pennec et al., 1990; Marty et al., 1992; Pernet and Tremblay, 2004; Soudant et al., 1996).

\section{Materials and methods}

\subsection{Broodstock sampling and conditioning}

Three-four year-old great scallops were collected by diving in the Bay of Brest (Finistère, France) in March 2011 and transferred to the Ifremer experimental hatchery of Argenton (Finistère, France). One hundred and twenty individuals (mean shell height: $108.5 \pm 0.7 \mathrm{~mm}$ ) were distributed in 8 tanks of 300 L (15 adults per tank). According to Mason macroscopic scale (Mason, 1958), modified by Robert et al. (1994), maturation stages ranged from 1 to 3 with 2 as 
mean value. Broodstock treatments carried out in duplicate corresponded to tanks equipped with coarse autoclaved sandy-bottom (SA) or without any sediment (NSA).

During conditioning, the photoperiod was maintained at 15:9 and tanks supplied with flowthrough filtered $(1 \mu \mathrm{m})$ and UV-treated seawater $\left(50 \mathrm{~L} \mathrm{~h}^{-1}\right)$. Broodstock were continuously fed with Pavlova lutheri (P), Tisochrysis lutea (T) and Skeletonema marinö̈ (S), at 1:1:1 equivalent volume and daily ration of $8 \times 10^{9}$ cells animal day ${ }^{-1}$. Two antibiotic treatments were applied during a 6 day-period in stagnant seawater with circulation pumps. The first when animals arrived at the hatchery and the second 4 weeks later. The selected antibiotic (see specific section 2.3 for details) was used at 8 ppm every two days corresponding to seawater renewal. The rest of the conditioning was realized in a continuous water flow. The temperature was raised at the beginning of the experiment by one degree per day until it reached $15^{\circ} \mathrm{C}$.

\subsection{Larval rearing}

After 7 weeks, $37 \%$ and $40 \%$ of the broodstocks spawned after thermal stimulation $\left(+5^{\circ} \mathrm{C}\right)$ for SA and NSA conditions respectively. Oocytes were fertilized as described in Gruffydd and Beaumont (1970). After $48 \mathrm{~h}$ of incubation in 150-L cylinder-cone shape tanks in stagnant seawater at $18^{\circ} \mathrm{C}, 19.5 \pm 7.9 \%$ and $41.2 \pm 0.2 \%$ of SA and NSA oocytes respectively hatched into D-larvae. Veliger larvae were reared in 5-L beakers in stagnant filtered $(1 \mu \mathrm{m})$ and UV-treated seawater, renewed each second day, at $18^{\circ} \mathrm{C}$. Each batch of larvae, originated from two previous broodstock treatments (SA and NSA), was exposed to two different larval treatments: NTwithout antibiotic, E- treated with selected antibiotic during 2 days (from 2 to 4 days postfertilization: dpf; Fig. 1).

The selected antibiotic (see specific section 2.3 for details) was added in rearing seawater at a concentration of $8 \mathrm{mg} \mathrm{L}^{-1}$ (Robert et al., 1996). Larvae, at an initial density of 10 veligers $\mathrm{mL}^{-1}$, 
were fed daily a PTS mixture at 60 cells $\mu 1^{-1}$ (1:1:1 equivalent volume). The experiment ended on day 15, at the beginning of the strict exotrophic larval phase to avoid potential confounding effect with trophic conditions.

\subsection{Selection of the tested antibiotic}

At the onset of the experiment, a portion of gonad and hemolymph of seven scallops were collected and homogenized in sterile seawater (SSW). After $10^{-1} \mathrm{SSW}$ dilution, $100 \mu \mathrm{l}$ of homogenate was plated onto marine agar. Small discs containing different antibiotics (erythromycin, penicillin, ampicillin, kanamycin, oxytetracycline, tetracycline, streptomycin, ticarcillin, chloramphenicol, flumequin, florfenicol, nalidixic acid, amoxicillin and gentamicin: Sigma-Aldrich, France) were laid in different zones of the culture (Gibson et al., 1998; Prado, et al., 2013; Riquelme et al., 1996) and inhibition zones were compared thereafter (Furones, 2001; Mayr-Harting et al., 1972). In our case, erythromycin appeared to be the most efficient antibiotic by presenting the cleanest and largest inhibition zone. This chemical agent have been used for all experiments described in this study.

\subsection{Monitoring of bacterial load}

Oocytes were sampled for bacterial analysis. During the larval rearing, bacterial concentration was achieved by sampling each larval replicate on a weekly basis. Total flora and Vibrio loads were estimated by the plate counting method, using marine agar and Thiosulfate-Citrate-Bile Salts-sucrose (TCBS) respectively (Azandegbe et al., 2010). They were expressed as Colony Forming Units, CFU larvae ${ }^{-1}$ or oocytes $^{-1}$ for each crushed sample (Thomas potter in sterile atmosphere before plate inoculation).

\subsection{Lipid analysis}


Samples of eggs (50 000) and 2 day-old larvae (25 000) were collected onto pre-combusted $\left(450^{\circ} \mathrm{C}\right)$ Whatman $\mathrm{GF} / \mathrm{C}$ filters, rinsed with $6 \%$ ammonium formate and stored at $-80^{\circ} \mathrm{C}$ in $2 \mathrm{ml}$ of $\mathrm{CH}_{2} \mathrm{Cl}_{2}-\mathrm{MeOH}$ (2:1), under nitrogen atmosphere. Lipids were extracted in dichloromethanemethanol (Folch et al., 1957) as described in Parrish (1987) and separated into neutral (including triglycerides, free fatty acids, and sterols) and polar (including mainly phospholipids) fractions as described in (Pernet et al, 2006). All fatty acid methyl esters (FAMEs) were prepared as described in Lepage and Roy (1984) and analysed in MSMS scan mode on a Polaris Q ion trap coupled to a Trace GC (Thermo Finnigan, Mississauga, ON, CA), as described in Gendron et al. (2013).

\subsection{Statistical analysis}

We used Permutational Analyses of Variances (PERMANOVA - PRIMER-E 6.0 PERMANOVA plus; PRIMER-E Ltd, Plymouth, UK) because of non-normal distribution of our larval rearing databases. This approach is more accurate than non-parametric analysis, because it uses similarities, like ANOVAs, but using the permutations method (9999 permutations). Only homoscedasticity must be verified by using the PERMDISP test (Anderson et al., 2008). When tTests were necessary, they were achieved using the software R (2012) following Shapiro-Wilk normality test. If data were not normal, Wilcoxon-Mann-Whitney tests were preferred to t-Tests.

For oocytes and D-larvae contamination, two-way cross PERMANOVAs, were performed to compare Vibrio and total flora contamination. Sources of variation in the PERMANOVA were: "Broodstock conditioning" (two fixed levels: NSA or SA) and "Ontogenic stage" (two fixed levels: oocytes and D-larvae) and their interaction. The resemblance matrixes were calculated on Euclidean distances as it was recommended by (Anderson, et al., 2008) for univariate analysis. 
For larval rearing data, two-way crossed PERMANOVAs, based on Euclidean resemblances, were realized for $10 \mathrm{dpf}$ and $15 \mathrm{dpf}$ separately, as homoscedasticity was not achieved when we include the factor "Date" (survival: $\mathrm{p}_{(\text {PERMDISP) }}=0.0001 ; \mathrm{F}_{(1-33)}=19.383$; Vibrio contamination: $\mathrm{p}_{(\text {PERMDISP })}=0.038 ; \mathrm{F}_{(1-33)}=7.911 ;$ total flora contamination: $\mathrm{p}_{(\text {PERMDISP })}=0.0001 ; \mathrm{F}_{(2-30)}=$ 28.43 ). Sources of variation in the PERMANOVAs were: "Broodstock conditioning" (two fixed levels: NSA or SA) and "Treatment" (two fixed levels: $\mathbf{E}$ or NT) and their interaction.

Univariate two-way crossed PERMANOVAs, based on Euclidean resemblances, were used to compare total fatty acids contents in the neutral and polar part of oocytes and D-larvae. Sources of variation were "Broodstock conditioning" (two levels fixed, NSA or SA), "Ontogenic stage" (two levels fixed, oocytes or D-larvae).

\section{Results}

\subsection{Bacterial load of oocytes and D-larvae before antibiotic treatment}

Estimated Vibrio load was higher for oocytes $(\mathrm{p}=0.00042 ; \mathrm{W}=187)$ and D-larvae $(\mathrm{p}=$ $0.0016 ; \mathrm{t}=5.47 ; \mathrm{df}=6)$ originated from broodstock conditioned with sediment $(\mathbf{S A})$ than without sediment (NSA) (Fig. 2A). It remained steady between oocytes and D-larvae in SA condition (p $=0.31 ; \mathrm{W}=24)$; whereas, the Vibrio load increased significantly from oocytes to D-larvae in NSA condition $(\mathrm{p}=0.00083 ; \mathrm{W}=0)$. However, NSA D-larvae Vibrio concentration remained 3.6 fold lower than in SA D-larvae (Fig. 2A).

Similar trends were observed when considering total flora of oocytes $(\mathrm{p}=0.00096 ; \mathrm{W}=186)$ and D-larvae ( $\mathrm{p}=0.047 ; \mathrm{t}=2.5 ; \mathrm{df}=6)$, with higher loads for gametes and offspring originated from SA broodstock (Fig. 2B). Regardless of conditioning treatments, total flora contamination increased significantly from oocytes to $\mathrm{D}$ larvae $(\mathbf{S A}: \mathrm{p}=0.000002 ; \mathrm{t}=-6.62 ; \mathrm{df}=20 ; \mathbf{N S A}: \mathrm{p}=$ $0.007 ; \mathrm{W}=3)$. The transfer of bacteria from oocytes to D-larvae was higher from broodstock 
conditioned without sediment (NSA: 7 fold increment) than in sand-bed (SA: 4.4 fold increment), but NSA amount did not reach total flora load of SA D-larvae (Fig. 2B).

\subsection{Larval survival and bacterial load after antibiotic treatment}

Regardless of date, no significant differences in larval survival (Fig. 3A) were observed when considering larval antibiotic treatment $\left(\mathrm{p}=0.881\right.$, Pseudo- $\mathrm{F}_{(1-11)}=0.02$ at $10 \mathrm{dpf} ; \mathrm{p}=0.34$, Pseudo- $\mathrm{F}_{(1-11)}=0.92$ at $\left.15 \mathrm{dpf}\right)$. In contrast, significant differences in larval survival were observed between broodstock conditioning procedures (NSA versus SA) on day $10(p=0.011$; Pseudo- $\left.\mathrm{F}_{(1-11)}=11.79\right)$ and $15\left(\mathrm{p}=0.017\right.$; Pseudo- $\left.\mathrm{F}_{(1-11)}=8.88\right)$. Larvae originated from NSA broodstock showed 52\% higher survival on days 15 (Fig. 3A) than SA broodstock.

Levels of Vibrio in D-larvae were close to 0 for all treatments, but increased over time until day 15 , when significant differences between broodstock conditioning factor $(\mathrm{p}=0.016$; Pseudo$\left.\mathrm{F}_{(1-11)}=12.03\right)$, with values more than two times higher in larvae originating from $\mathbf{S A}$ broodstock (Fig. 3B). In contrast, larval antibiotic treatment between 2 to 4 days post-fertilization did not induce significant differences in Vibrio load of larvae at day $10\left(\mathrm{p}=0.71\right.$; Pseudo- $\left.\mathrm{F}_{(1-11)}=0.16\right)$ and $15\left(\mathrm{p}=0.60 ;\right.$ Pseudo- $\left.\mathrm{F}_{(1-11)}=0.298\right)($ Fig. 3B). Similar trends were observed for total flora load in larvae but no significant differences related to broodstock conditioning or antibiotic factor were found due to high heterogeneity between replicates (Fig. 3C).

\subsection{Characteristics of oocytes and larvae lipids}

Fatty acids profiles of the neutral and polar lipid fraction of oocytes and D-larvae are given in Table 1. Considering the effects of broodstock conditioning, no significant differences were detected in oocytes and D-larvae fatty acids composition of each fraction (neutral: $\mathrm{p}=0.60$; Pseudo- $\mathrm{F}_{(1-31)}=0.6$; polar: $\mathrm{p}=0.22 ;$ Pseudo- $\left._{(1-31)}=1.5\right)$. 
When considering total fatty acids content (Table 1), no significant differences were observed for the factor "Broodstock conditioning" in any lipid fraction (Neutral: $\mathrm{p}=0.52$; Pseudo- $\mathrm{F}_{(1-31)}=$ 0.42 and Polar: $\mathrm{p}=0.89$; Pseudo- $\left.\mathrm{F}_{(1-31)}=0.019\right)$.

\section{Discussion}

\subsection{Broodstock conditioning and gametes contamination}

Oocytes originating from scallops conditioned in tanks with sediments (SA) were more contaminated by bacteria, and specifically by Vibrio. Despite the use of autoclaved sediment, the accumulation of algae and feces created an organic matter layer, which might favor bacterial development (Essid et al., 2007; La Rosa et al., 2004; Richardson et al., 2008). The prophylactic

measures implemented in the sandy-bottom tanks were clearly inefficient because bacteria accumulated significantly in SA oocytes. Moreover, sediment is known to act as a bacterial reservoir (Chelossi et al., 2003), which could be a major source of broodstocks microbial contamination. Vibrios are prevalent in the bivalve microflora (MacGladdery et al., 2006; Pruzzo et al., 2005). They are resistant to digestion and able to become established in the digestive tract of bivalves (Prieur et al., 1990). In P. maximus, the intestine is partially included in the gonad where it makes a loop (Le Pennec et al., 1992). Tissues transfer could be promoted and facilitate infection of gonads and specifically maturing oocytes (Beninger et al., 2003). This anatomic particularity could support the idea of a direct vertical transfer between scallops and gametes.

\subsection{Bacterial load of gametes and larval survival}

Oocytes and D-larvae originated from broodstock conditioned with or without sediment exhibited similar quantities of neutral and polar lipids as well as similar FA profiles (Table 1). Broodstock were accordingly conditioned with the same diet and, despite a potential trapping of 
food by sediment, it did not interfere with storage and gamete biochemical composition. Neutral lipids or triacylglycerols are the primary endogenous energy reserve fueling basal metabolism in bivalve larvae (Ben Kheder et al., 2010a, b; Gallager and Mann, 1986; Holland and Spencer, 1973). Thus, differential performances of larvae that originated from SA or NSA broodstock (20 and $80 \%$ survival, on $15 \mathrm{dpf}$, respectively) were not related to lipids content. In contrast, Vibrio loads were higher for SA larvae on day 15 and might explain the differential mortality recorded. Indeed, it has been reported that larval rearing can collapse when Vibrio concentration is very low during spawning (Luna-González et al., 2002). Sediment allows bacterial development by getting them substrate and organic matter (Essid et al., 2007; La Rosa et al., 2004; Richardson et al., 2008) and explained undoubtedly the earlier mortality of SA larvae more contaminated initially (day 2).

A short and early erythromycin treatment (two consecutive days from day 2 to 4 ), based on brodstock bacterial flora, did not improve long-term $P$. maximus larval performance. The selection of suitable antibiotic by antibiograms, to depress bacterial flora is considered as a good long-term solution for fish farming by Furones (2001). Each group of broodstocks is specific and often associated to particular bacterial communities, which can be more or less sensitive to a given antibiotic. The use of erythromycin during broodstock conditioning could have favored the development of some less sensitive bacteria, which could thereafter be found in the gametes. We suggest that the different bacterial loads registered in oocytes and D-larvae could correspond to bacteria less sensitive to this specific antibiotic.

\section{Conclusion}

In a way to limit bacterial transfer from adults to their gametes and D-larvae, we exposed in this study the advantages of removing sediment during scallops' broodstock conditioning. As 
broodstock were not physiologically affected by the privation of substrate, sediment could clearly be removed from traditional scallop conditioning method (like French hatcheries). Unfortunately, the test, which aimed to reduce antibiotic treatment of batch culture until metamorphosis by a short specific treatment of two days applied on D-larvae, didn't improve the short-term survival of larvae. The application of this prophylactic method for reducing gametes contamination could be investigated with the subsequent use of flow-through larval rearing.

\section{Acknowledgements}

The authors would like to thank the technician team of Ifremer's Argenton station - C. Mingant, I. Quéau, L. Lebrun, and P. Le Souchu - for algal production and technical support. We are also grateful to the "Ministère du Développement Economique, de l'Innovation et de l'Exportation " (MDEIE), which contributed to the funding of a $\mathrm{PhD}$ scholarship and to "Ressource Aquatiques Québec" (RAQ), and "Fonds de Recherches Québécois en sciences Naturelles et Technologie "(FRQNT), for travel grant to M. Holbach. This work was carried out during the UE funded ReproSeed project (FP7-KBBE 245119), which contributed to its functional outlays.

\section{References}

Akinbowale, O.L., Peng, H., Barton, M.D., 2006. Antimicrobial resistance in bacteria isolated from aquaculture sources in Australia. J. Appl. Micobiol. 100, 1103-1113.

Andersen, S., Christophersen, G., Magnesen, T., 2011. Spat production of the great scallop (Pecten maximus): a roller coaster11. Can. J. Zool. 89, 579-598.

Anderson, M., Gorley, R., Clarke, K., 2008. Plymouth: Primer-E; 2008. PERMANOVA+ for PRIMER: Guide to software and statistical methods, 214. 
Avendaño-Herrera, R., Dekovic, M., Riquelme, C., 2001. Establishment of beneficial bacteria in the digestive tract and gonads of adult Argopecten purpuratus (Lamarck 1819) in mass culture. Rev. Biol. Mar. Ocaenogr. 36, 31-41.

Azandegbe, A., Garnier, M., Andrieux, F., Kerouel, R., Philippon, X., Nicolas, J.L., 2010. Occurrence and seasonality of Vibrio aestuarianus in sediment and Crassostrea gigas haemolymph at two oyster farms in France. Dis. Aquat. Organ., 91(3), 213-221.

Ben Kheder, R., Quéré, C., Moal, J., Robert, R., 2010a. Effect of nutrition on Crassostrea gigas larval development and the evolution of physiological indices. Part A: Quantitative and qualitative diet effects. Aquaculture. 305, 165-173.

Ben Kheder, R., Quéré, C., Moal, J., Robert, R., 2010b. Effect of nutrition on Crassostrea gigas larval development and the evolution of physiological indices: Part B: Effects of temporary food deprivation. Aquaculture. 308, 174-182.

Beninger, P.G., Le Pennec, G., Le Pennec, M., 2003. Demonstration of nutrient pathway from the digestive system to oocytes in the gonad intestinal loop of the scallop Pecten maximus L. Biol. Bull. 205, 83-92.

Buestel, D., Cochard, J.-C., Dao, J.-C., Gerard, A., 1982. Production artificielle de naissain de coquilles Saint-Jacques Pecten maximus (L.). Premiers résultats en rade de Brest. Vie Marine Annales de la Fondation océanographique Ricard. 4, 24-28.

Chelossi, E., Vezzulli, L., Milano, A., Branzoni, M., Fabiano, M., Riccardi, G., Banat, I.M., 2003. Antibiotic resistance of benthic bacteria in fish-farm and control sediments of the Western Mediterranean. Aquaculture. 219, 83-97.

Cordero O. X., Wildschutte H., Kirkup B., Proehl S., Ngo L., Hussain F., Le Roux F, Mincer T., Polz M. F. (2012). Ecological Populations of Bacteria Act as Socially Cohesive Units of Antibiotic Production and Resistance. Science, 337(6099), 1228-1231.

Dao, J.C., Barret, J., Devauchelle, N., Fleury, P.G., Robert, R., 1995. Rearing of scallops (Pecten maximus) in France, from hatchery to intermediate culture, results of a 10 years programme (1983-1993). In: Proceedings of a Workshop on Fish and Mollusc Larviculture, 121-134 "Improvement of the Commercial Production of Marine Aquaculture Species". Gajardo, G. et Coutteau, P. (eds), Impresora Creces, Santiago, Chile.

Delaunay, F., Marty, Y., Moal, J., Samain, J.F., 1992. Growth and lipid class composition of Pecten maximus (L.) larvae grown under hatchery conditions. J. Exp. Mar. Biol. Ecol. 163, 209219.

Devauchelle, N., Mingant, C., 1991. Review of the reproductive physiology of the scallop, Pecten maximus, applicable to intensive aquaculture. Aquat. Living Resour. 4, 41-51. 
Elston, R., Leibovitz, L., 1980. Pathogenesis of Experimental Vibriosis in Larval American Oysters, Crassostrea virginica. Can. J. Fish. Aquat. Sci. 37, 964-978.

Essid, N., Mahmoudi, E., Boufahja, F., Dellali, M., Beyrem, H., Aissa, P., 2007. Impact of mussel pseudo-feces on heterotrophic bacteria densities in the mussel farm sector of the Bizerte Lagoon (Tunisia). Revue des Sciences de l'Eau. 20, 383-392.

Folch, J., Lees, M., Sloane-Stanley, G., 1957. A simple method for the isolation and purification of total lipids from animal tissues. J. Biol. Chem. 226, 497-509.

Furones, M.D., 2001. Sampling for antimicrobial sensitivity testing: a practical consideration. Aquaculture. 196, 303-309.

Gagné, R., Tremblay, R., Pernet, F., Miner, P., Samain, J.-F., Olivier, F., 2010. Lipid requirements of the scallop Pecten maximus (L.) during larval and post-larval development in relation to addition of Rhodomonas salina in diet. Aquaculture. 309, 212-221.

Gallager, S.M., Mann, R., 1986. Growth and survival of larvae of Mercenaria mercenaria (L.) and Crassostrea virginica (Gmelin) relative to broodstock conditioning and lipid content of eggs. Aquaculture. 56, 105-121.

Gendron, L., Tremblay, R., Belvin, S., Genard, B., Motnikar, S., Côté, J. 2013. Condition, survival and growth in situ of hatchery-reared stage IV lobster (Homarus americanus) fed Artemia and lipid-rich wild zooplankton. Aquaculture 416-417, 380-389.

Gibson, L.F., Woodworth, J., George, A.M., 1998. Probiotic activity of Aeromonas media on the Pacific oyster, Crassostrea gigas, when challenged with Vibrio tubiashii. Aquaculture. 169, 111120.

Glencross, B.D., Smith, D.M., 2001. A study of the arachidonic acid requirements of the giant tiger prawn, Penaues monodon. Aquacult. Nutr. 7, 59-69.

Gruffydd, L.D., Beaumont, A.R., 1970. Determination of the optimum concentration of eggs and spermatozoa for the production of normal larvae in Pecten maximus (Mollusca, Lamellibranchia). Helgoland Mar. Res. 20, 486-497.

Gruffydd, L.D., Beaumont, A.R., 1972. A method for rearing Pecten maximus larvae in the laboratory. Mar. Biol. 15, 350-355.

Helm, M.M., Bourne, N., Lovatelli, A., 2004. Hatchery culture of bivalves: A practical manual. FAO Fisheries Technical Paper. No. 471. FAO, Rome. 
Holland, D.L., Spencer, B.E., 1973. Biochemical changes in fed and starved oysters, Ostrea edulis L. during larval development, metamorphosis and early spat growth. J. Mar. Biol. Assoc. U.K. 53, 287-298.

La Rosa, T., Mirto, S., Mazzola, A., Maugeri, T.L., 2004. Benthic microbial indicators of fish farm impact in a coastal area of the Tyrrhenian Sea. Aquaculture. 230, 153-167.

Lambert, C., Nicolas, J.L., Cilia, V., Corre, S., 1998. Vibrio pectenicida sp. nov., a pathogen of scallop (Pecten maximus) larvae. Int. J. Syst. Bacteriol. 48, 481-487.

Le Pennec, M., Prieur, D., 1977. Les antibiotiques dans les élevages de larves de bivalves marins. Aquaculture. 12, 15-30.

Le Pennec, M., Guguen, F., Cochard, J.C., Paulet, Y.M., Dorange, G., 1990. Relations entre le contenu lipidique des ovocytes de Pecten maximus (Mollusque, bivalve) et les performances des larves en élevage. Haliotis. 10, 101-113.

Le Pennec, M., Dorange, G., Beninger, P., Donval, A., Widowati, I., 1992. Trophic relationships gonad-intestinal loop in Pecten maximus. Soc. Franc. Malaco. 13, 57-70.

Lepage, G., Roy, C.C., 1984. Improved recovery of fatty acid through direct transesterification without prior extraction or purification. J. Lipid Res. 25, 1391-1396.

Lodeiros, C., Bolinches, J., Dopazo, C.P., Toranzo, A.E., 1987. Bacillary necrosis in hatcheries of Ostrea edulis in Spain. Aquaculture. 65, 15-29.

Loosanoff, V.L., Davis, H.C., 1963. Rearing of Bivalve Mollusks. in: Russell, F.S. (Ed.), Advances in Marine Biology. Academic Press, pp. 1-136.

Luna-González, A., Maeda-Martinez, A., Sainz, J., Ascencio-Valle, F., 2002. Comparative susceptibility of veliger larvae of four bivalve mollusks to a Vibrio alginolyticus strain. Dis. Aquat. Organ. 49, 221-226.

MacGladdery, S.E., Bower, S.M., Getchell, R.G., 2006. Chapter 11 : Diseases and parasites of scallops. in: Sandra E., S., Jay G., P. (Eds.), Developments in Aquaculture and Fisheries Science. Elsevier, pp. 595-650.

Magnesen, T., Bergh, O., Christophersen, G., 2006. Yields of great scallop, Pecten maximus, larvae in a commercial flow through rearing system in Norway. Aquacult. Int. 14, 377-394.

Marty, Y., Delaunay, F., Moal, J., Samain, J.F., 1992. Changes in the fatty acid composition of Pecten maximus (L.) during larval development. J. Exp. Mar. Biol. Ecol. 163, 221-234. 
Mason, J., 1958. The breeding of the scallop, Pecten maximus (L.), in Manx waters. J. Mar. Biol. Assoc. U.K. 37, 653-671.

Mayr-Harting, A., Hedges, A.J., Berkeley, R.C.W., 1972. Methods for studying bacteriocins. Method. Microbiol. 7A, 315-422.

Nicolas, J.L., Corre, S., Gauthier, G., Robert, R., Ansquer, D., 1996. Bacterial problems associated with scallop Pecten maximus larval culture. Dis. Aquat. Organ. 27, 67-76.

Parrish, C.C., 1987. Separation of aquatic lipid classes by chromarod thin-layer chromatography with measurement by iatroscan flame ionization detection. Can. J. Fish. Aquat. Sci. 44, 722-731.

Pernet, F., Tremblay, R., 2004. Effect of varying levels of dietary essential fatty acid during early ontogeny of the sea scallop Placopecten magellanicus. J. Exp. Mar. Biol. Ecol. 310, 73-86.

Pernet F., Pelletier C.J., Milley J., 2006, Comparison of three solid- phase extraction methods for fatty acid analysis of lipid fractions in tissues of marine bivalves. J. Chromatogr. A 1137, 127137.

Prado, S., Dubert, J., da Costa, F., Martínez-Patiño, D., Barja, J.L., 2013. Vibrios in hatchery cultures of the razor clam, Solen marginatus (Pulteney). J. Fish Dis. 37, 209-217.

Prieur, D., Mevel, G., Nicolas, J., Plusquellec, A., Vigneulle, M., 1990. Interactions between bivalve molluscs and bacteria in the marine environment. Oceanogr. Mar. Biol. Annu. Rev. 28, 277-352.

Pruzzo, C., Gallo, G., Canesi, L., 2005. Persistence of vibrios in marine bivalves: the role of interactions with haemolymph components. Environ. Microbiol. 7, 761-772.

Richardson, N., Ruesink, J., Naeem, S., Hacker, S., Tallis, H., Dumbauld, B., Wisehart, L., 2008. Bacterial abundance and aerobic microbial activity across natural and oyster aquaculture habitats during summer conditions in a northeastern Pacific estuary. Hydrobiologia. 596, 269-278.

Riquelme, C., Chavez, P., Morales, Y., Hayashida, G., 1994. Evidence of a parental bacterial transfer to larvae in Argopecten purpuratus (Lamack, 1819). Biol. Res. 27, 129-134.

Riquelme, C., Hayashida, G., Araya, R., Uchida, A., Satomi, M., Ishida, Y., 1996. Isolation of a native bacterial strain from the scallop Argopecten purpuratus with inhibitory effects against pathogenic vibrios. J. Shellfish Res. 15, 369-374.

Robert, R., Miner, P., Nicolas, J.L., 1996. Mortality control of scallop larvae in the hatchery. Aquacult. Int. 4, 305-313. 
Robert, R., Miner, P., Mazuret, M., Connan, J.-P., 1994. Ecloserie expérimentale de mollusques d'Argenton, bilan et perspective. Equinoxe. 49, 20-33.

Sainz-Hernández, J.C., Maeda-Martínez, A.N., 2005. Sources of Vibrio bacteria in mollusc hatcheries and control methods: a case study. Aquac. Res. 36, 1611-1618.

Soudant, P., Marty, Y., Moal, J., Samain, J.-F., 1996. Fatty acids and egg quality in great scallop. Aquacult. Int. 4, 191-200.

Torkildsen, L., Lambert, C., Nylund, A., Magnesen, T., Bergh, Ø., 2005. Bacteria associated with early life stages of the great scallop, Pecten maximus: impact on larval survival. Aquacult. Int. 13, 575-592.

Uriarte, I., Farías, A., Castilla, J.C., 2001. Effect of antibiotic treatment during larval development of the Chilean scallop Argopecten purpuratus. Aquacult. Eng. 25, 139-147.

Utting, S.D., Millican, P.F., 1997. Techniques for the hatchery conditioning of bivalve broodstocks and the subsequent effect on egg quality and larval viability. Aquaculture. 155, 4554.

Walne, P.R., 1966. Experiments in the large-scale culture of the larvae of Ostrea edulis L. Fish. Invest., Ser. II. 25. 
Fig. 1: Schematic of the experimental design: NT- without antibiotic, E- 2 days selected antibiotic treatment.

Fig. 2: Mean oocytes and D-larvae bacterial contamination (mean $\pm \mathrm{SE}$ ) between two different broodstock conditioning: SA, presence of sandy-bottom and NSA, without any sediment. AVibrio load and B- total flora (CFU oocyte ${ }^{-1}$ or CFU larva $^{-1}$ ). Different letters show significant differences $\mathrm{p}<0.05$. Capital and lowercase letters correspond to separate analyses.

Fig. 3: A- Larval survival (\%); B- Vibrio contamination (CFU larva ${ }^{-1}$ ) of larvae into four different conditions. SA - NT: Presence of sediment during broodstock conditioning and larvae reared without antibiotic; SA - E: Presence of sediment during broodstock conditioning and larvae reared with erythromycin treatment between 2 to 4 days post-fertilization; NSA - NT: Absence of sediment during broodstock conditioning and larvae reared without antibiotic; NSA - E: Absence of sediment during broodstock conditioning and larvae reared with erythromycin treatment between 2 to 4 days post-fertilization; C- Mean of total flora contamination of larvae during larval rearing ( $\mathrm{CFU}$ larva $\left.^{-1}\right)$, data were pooled as there were no statistical differences. Asterisk indicates significant differences $(\mathrm{p}<0.05)$. Asterisks correspond to the two $\mathbf{S A}$ conditions (mean \pm $\mathrm{SE})$. 


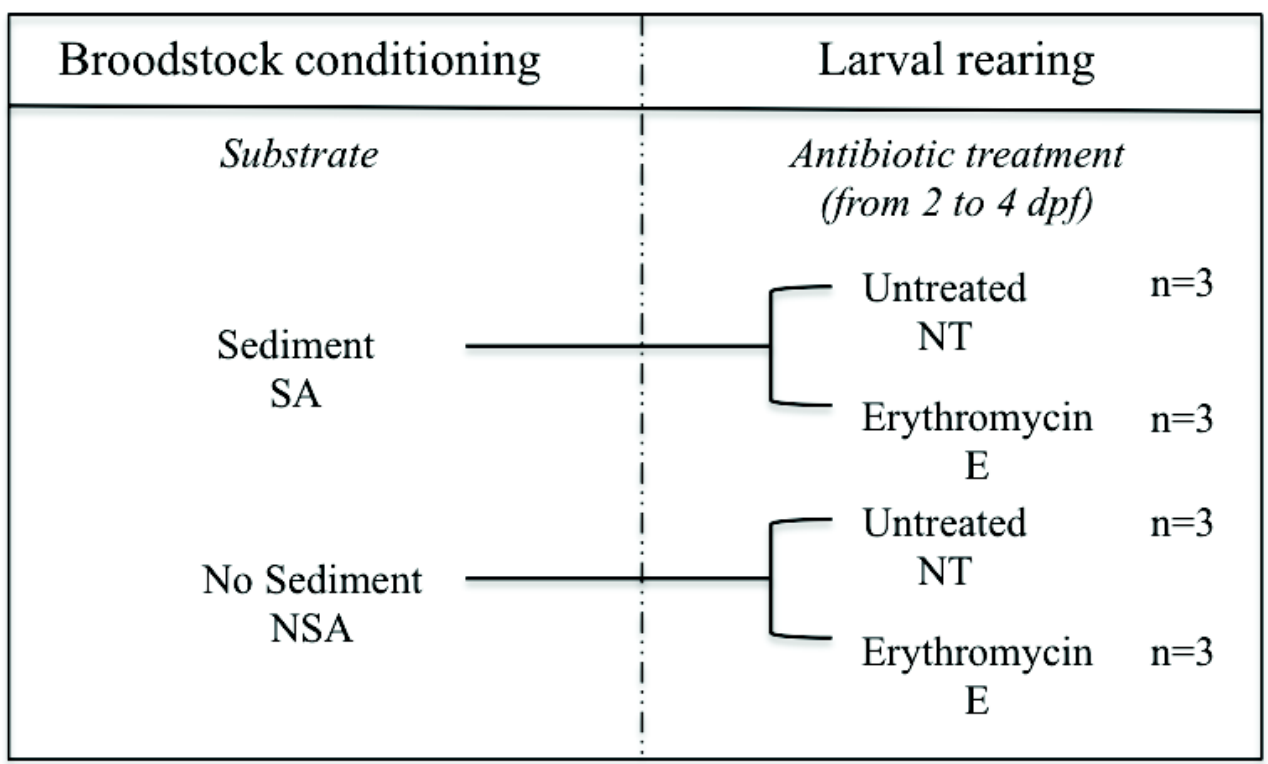

Fig. 1 

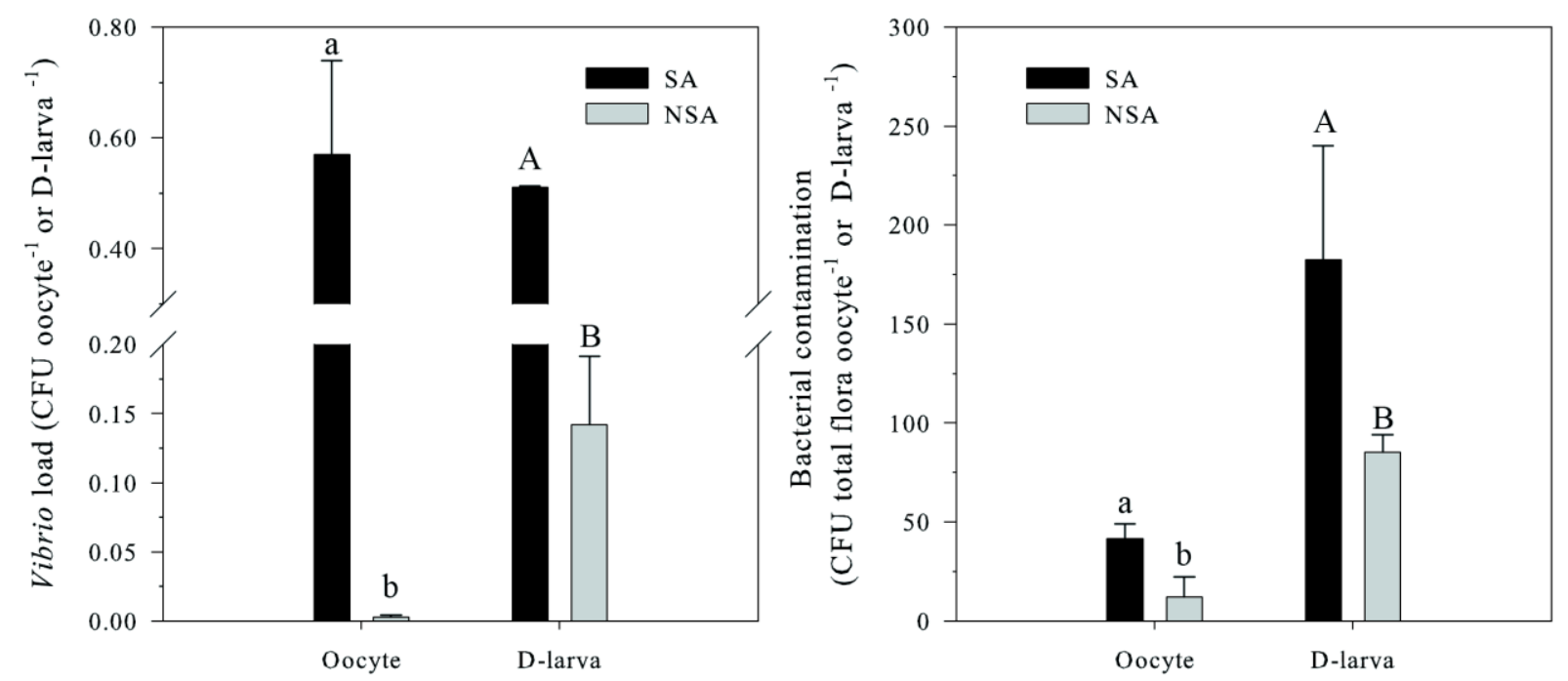

Fig. 2 

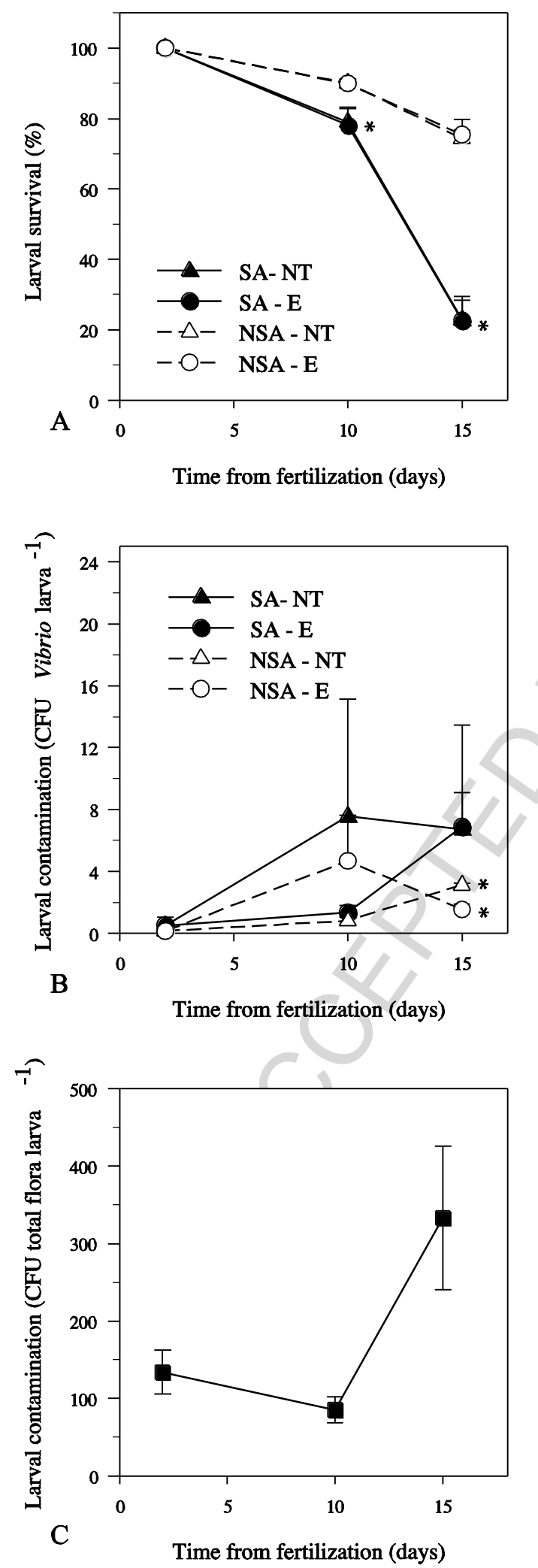

Fig. 3 
Table 1: Fatty acids profiles of neutral and polar fractions from oocytes and D-larvae. Data obtained from sediment and non-sediment conditionings were pooled as they were nonsignificant. Values in bold represent essential fatty acids contributing to differences between oocytes and D-larvae for each lipid fraction. Results are express as \% of total fatty acid (mean \pm SE).

\begin{tabular}{lrrrrr}
\hline & \multicolumn{2}{c}{ Neutral } & \multicolumn{2}{c}{ Polar } \\
\cline { 2 - 7 } & \multicolumn{1}{c}{ Oocytes } & \multicolumn{1}{c}{ D-larvae } & \multicolumn{1}{c}{ Oocytes } & D-larvae \\
\hline C14:0 & $5.9 \pm 0.51$ & $2.1 \pm 2.08$ & $1.1 \pm 1.13$ & $0.0 \pm 0.00$ \\
C15:0 & $0.2 \pm 0.07$ & $0.0 \pm 0.00$ & $0.0 \pm 0.00$ & $0.0 \pm 0.00$ \\
C16:0 & $15.6 \pm 0.28$ & $20.5 \pm 0.95$ & $9.8 \pm 1.11$ & $7.6 \pm 2.59$ \\
C17:0 & $0.0 \pm 0.00$ & $0.0 \pm 0.00$ & $0.0 \pm 0.00$ & $0.0 \pm 0.00$ \\
C18:0 & $1.9 \pm 0.18$ & $0.3 \pm 0.08$ & $5.1 \pm 0.18$ & $4.1 \pm 1.33$ \\
C22:0 & $0.2 \pm 0.05$ & $1.2 \pm 0.59$ & $0.1 \pm 0.09$ & $0.0 \pm 0.00$ \\
$\Sigma$ SFA & $23.8 \pm 0.38$ & $24.1 \pm 0.62$ & $16.1 \pm 1.97$ & $11.7 \pm 3.91$ \\
C16:1 (n-7) & $4.4 \pm 1.96$ & $10.9 \pm 1.00$ & $0.2 \pm 0.20$ & $0.0 \pm 0.00$ \\
C17:1 (n-7) & $0.1 \pm 0.15$ & $0.0 \pm 0.00$ & $4.4 \pm 1.48$ & $2.4 \pm 0.56$ \\
C18:1 (n-9) & $2.4 \pm 1.36$ & $0.0 \pm 0.00$ & $0.2 \pm 0.20$ & $0.0 \pm 0.00$ \\
$\Sigma$ MUFA & $7.0 \pm 0.74$ & $10.9 \pm 1.00$ & $4.8 \pm 1.48$ & $2.4 \pm 0.56$ \\
C18:2(n-6) & $2.2 \pm 0.19$ & $0.0 \pm 0.00$ & $0.0 \pm 0.00$ & $0.0 \pm 0.00$ \\
C18:3 (n-6) & $9.1 \pm 0.38$ & $2.4 \pm 2.39$ & $4.8 \pm 0.10$ & $19.2 \pm 1.74$ \\
C18:3(n-3) & $2.4 \pm 0.06$ & $4.8 \pm 0.43$ & $0.5 \pm 0.28$ & $0.0 \pm 0.00$ \\
C18:4 (n-3) & $9.2 \pm 0.36$ & $2.3 \pm 2.31$ & $4.8 \pm 0.06$ & $18.8 \pm 1.72$ \\
C20:3(n-6) & $0.8 \pm 0.05$ & $0.0 \pm 0.00$ & $0.2 \pm 0.16$ & $0.0 \pm 0.00$ \\
C20:3(n-3) & $0.1 \pm 0.09$ & $1.6 \pm 0.55$ & $0.0 \pm 0.00$ & $0.0 \pm 0.00$ \\
C20:4 (n-6) (AA) & $\mathbf{2 . 4} \pm \mathbf{0 . 0 1}$ & $\mathbf{1 . 5} \pm \mathbf{0 . 0 5}$ & $\mathbf{5 . 3} \pm \mathbf{0 . 1 5}$ & $\mathbf{5 . 0} \pm \mathbf{0 . 2 2}$ \\
C20:5(n-3) (EPA) & $\mathbf{2 5 . 4} \pm \mathbf{0 . 1 3}$ & $\mathbf{2 2 . 3} \pm \mathbf{4 . 0 6}$ & $\mathbf{2 2 . 4} \pm \mathbf{2 . 2 0}$ & $\mathbf{1 1 . 7} \pm \mathbf{0 . 3 8}$ \\
C22:6(n-3) (DHA) & $\mathbf{1 7 . 6} \pm \mathbf{0 . 8 7}$ & $\mathbf{3 0 . 1} \pm \mathbf{0 . 3 1}$ & $\mathbf{4 1 . 1} \pm \mathbf{2 . 8 1}$ & $\mathbf{3 1 . 4} \pm \mathbf{0 . 4 9}$ \\
$\Sigma$ PUFA & $69.2 \pm 0.35$ & $65.0 \pm 0.39$ & $79.0 \pm 0.49$ & $85.9 \pm 3.35$ \\
$\Sigma$ EFA & $45.3 \pm 1.02$ & $53.9 \pm 4.43$ & $68.8 \pm 0.76$ & $48.0 \pm 0.11$ \\
Total (pg individual ${ }^{-1}$ ) & $\mathbf{2 2 7} \pm \mathbf{8}$ & $\mathbf{1 1 2} \pm \mathbf{1 4}$ & $\mathbf{6 7} \pm \mathbf{2 . 5}$ & $\mathbf{9 3} \pm \mathbf{1 1 . 7}$ \\
\hline & & & & & \\
\hline
\end{tabular}

